\title{
EVALUATION OF SPRAY DISTRIPTION FOR LOW \\ PRESSURE EMTF NOZZLES
}

\author{
Sehsah, E.M.E*
}

\begin{abstract}
The full automatic patternometer was used with ultrasonic sensor and compatible software program to measure the spray distribution from different EMTF nozzles under conditions of JKI laboratory in Germany. The goals of present study are measured spray distribution of the EMTF nozzles using the full automatic patternometer single nozzle test, by comparing the distribution profiles of sprays from EMTF nozzles those from standard fan nozzles. As well as investigating to find the optimum combination for EMTF nozzles from the available nozzles in the marketing which may be produced a good uniformity spray distribution. The current investigation research was cared out in the Federal Biological Research Centre for Agriculture and Forestry (JKI), Braunschweig, Germany. The full automatic patternometer was adapted at the optimum air conditions, $20^{\circ} \mathrm{C}$ air temperature and $80 \%$ relative humidity. Eight external mixing twin fluid nozzles were evaluated in a patternometer single nozzle test to compare spray distribution. Each tip was compared at $60 \mathrm{kPa}$ liquid pressure, parallel to a $150 \mathrm{kPa}$ and 200 $\mathrm{kPa}$ air pressure for each. Two levels for nozzle height $50 \mathrm{~cm}$ and $70 \mathrm{~cm}$, and co-angling $45^{\circ}$ and $60^{\circ}$ was treated and studied their effect with the interaction of both nozzles and air pressure on coefficient of variation percent. The results indicated that the minimum CV \% values for good spray distribution were $10.6 \%, 12.9 \%$ and $14.0 \%$ for EMTF nozzle N8, $\mathrm{N} 3$ and $N 7$ at $50 \mathrm{~cm}$ nozzle height, $45^{\circ}$ co-angling and 200 air pressure respectively. The EMTF nozzle $N 8$ produced the $C V \%$ nearly the standard ISO nozzle CV percentages values. The uniformity spray distribution CV percent values for N8 (Lechler FT 5-608 \& DG800-04 $V K)$ nozzle at the optimum co-angling $45^{\circ}$ were $11.0 \%$ and $12.1 \%$ at 50 $\mathrm{cm}$ and $70 \mathrm{~cm}$ nozzle height respectively.
\end{abstract}

*Dr. Sehsah, El-Sayed El-Beily, Dept. of Agric. Eng. Faculty of Agric., Kafr El-Sheikh University, 33516- Kafr El-Sheikh, Egypt. E-maillsehsah_2000@yahoo.de 
As well as, there are non effects of the interaction of air pressures with the all factors on the $C V$ percentage. It may therefore be concluded that the $C V \%$ values are more strongly dependant on the combinations of nozzles in the EMTF nozzles, which is highly significant in data.

Key words: Spray distribution, Nozzles. Low pressure

\section{INTRODUCTION}

A basic approach to select a spray based on the pattern and other spray characteristics needed, generally, yields good results. The spray selection should be considered early in the design of the system. Although spray considering that the spectrum of standardized sprays currently in existence is so large. A distribution quality test gives the applicator important information about the state of the nozzles on the boom. When it has much more detailed information about spray quality and coverage are required, a dynamic system spraying a tracer (dye) can be used.

Koch and Weisser (1996) clearly demonstrated the importance of dynamic factors; they stated that, spray distribution, measured under static conditions on a patternator, does not represent the pattern achieved in routine dynamic applications. Each specific sprayer configuration defined by nozzle type, spraying height, pressure and speed yields in a specific horizontal dynamic distribution pattern that is unpredictable and shows tangential strips of distinct deposit levels on targets within the sprayed area. Deposition can vary more than $80 \%$ and the average actual quantity of deposit was normally much lower than that calculated because of fan geometry and spray losses outside the sprayed area. To avoid misinterpretation, when dose response was investigated, it was necessary to identify the specific dynamic transversal distribution pattern of any sprayer configuration used in tests in order to as sure that dose levels within the sprayed area were known and can be related to target positions below or between nozzle positions. They also stated that the prediction of deposition on targets from distribution measurements on a patternator was an assumption rather than a scientifically proven result.

Hagenvall (1981) concluded that poorer weed control was obtained at greater boom heights despite low measured coefficients of variation. It should be noted that nozzle height can be critical for $\mathrm{CV}$ measurement 
even for flat fan nozzles, with $80^{\circ}$ flat fan nozzles tending to give more variable CVs than $110^{\circ}$ over standard boom operating heights. Richardson et al. (1985) indicated that the spray pressure can also significantly affect CVs with the same nozzle. The combination of chosen testing height and pressure therefore will affect CVs from each particular nozzle.

Koch (1992), Sinfort and Herbst (1996), Richards et al. (1997) clearly demonstrated that spray distribution on stationary patternator had limited correlation with uniformity of spray deposits on natural targets in the field. The European SPECS project, and other work, shows that coefficients of variation of $7-9 \%$ achieved on a static patternator under laboratory conditions can translate to values of over $30 \%$ under field conditions.

Richardson et al. (2000) showed that a study on aerial herbicide application in New Zealand, there appeared to be little effect on herbicide efficacy of CVs of up to 30\%, supporting the study by Enfalt et al, (1997a and 1997b), and possibly even higher. Krishnan et al. (2005) studied the effects of spray boom deflection, wind velocity, and wind direction on spray pattern displacement (SPD) of extended range of 110-0 fan nozzles by using Patternator. Tests were conducted at four nozzle pressures of $139,208,313$ and $383 \mathrm{kPa}$. At each pressure, tests were conducted at four wind conditions (including combinations of both cross and head wind), two spray boom deflections of 0.2 and $0.4 \mathrm{~m}$ amplitude, and a frequency of $1 \mathrm{~Hz}$. spray boom deflection, wind velocity and wind direction significantly $(\mathrm{P}<0.05)$ affected SPD values at 139-, 208-, and 313-kPa nozzle pressure. However, coefficient of variation (C.V., \%) values of $8.5 \%$ to $13.5 \%$ obtained from these tests indicated uniform or acceptable coverage.

Sehsah and Kleisinger (2009) indicated that the spray distribution is improved by increasing nozzle size, pressure and reduces the nozzle height. The type of nozzles is very important parameters which affect the distribution of pattern (C.V.\%). The selection of nozzles may be reduced the losses of spray dose and gives good distribution of pattern.

The main objectives of this current study are investigated and evaluate the spray distribution from external mixing twin fluid nozzles by comparing 
with the standard spray nozzles. To find also the optimal nozzle configuration in the different selected EMTF nozzles combinations.

\section{MATERIAL AND METHODS}

The current study was designed to measure the amount of spray distribution from different combinations of external mixing twin fluid nozzles in a Patternator single nozzle test. Initially, the pattern data collection was attempted using the full automatically method, i.e. using the ultrasound sensor with programming mechanical patternator.

\section{Ultrasonic sensor}

The programmable ultrasonic sensor Di-Sonic USE46K1500PSKT-TSSL provide high-resolution control of switch point-span settings, compensation for turbulent or unstable target surfaces, and access to extended sensing ranges as well as other parameters. The measured distance range for the above mentioned Ultrasonic sensor is $0 \mathrm{~mm}$ to 1500 mm. To simplify the sensor programming procedure, AW software program is available that provides an instant communications link between an RS-232 programmable ultrasonic sensor Di-Sonic and a Windows-based computer. A programmable sensor could be advantageous in a variety of applications, including distance measuring in tight spaces and liquid level control for tubs in Patternator.

\section{Spray liquid measurement level setup}

The Ultrasonic sensor Di-Sonic was mounted in rubber elevator which driven by an electric motor. The electric motor was moved from the end of the lift side to the right side in the Patternator. In addition, the eclectic motor controlled by the AW programming system and it was programmed to move over every tube in the Patternator as shown in figure 1. The Ultrasonic sensor was moved over the top of every tube in the Patternator and measured the distance that indicated the spray liquid levels for each tube. These distances of the spray levels for each tube send to the software program to calculate the spray volume for each tube, flow rate, and coefficient of variation CV \%. The software AW package from the AW-SYSTEMS GmbH, Am Exer Sr. 10 d-38302 Wolfenbüttel, Germany was used to controlled and measured the relative humidity, liquid pressure, flow-rate for each tube, total flow rate and coefficient of 
variation percentages (CV \%). By computer analysis, from the levels recorded in the patternator tubes for the single candidate nozzle, calculate the distribution for a 3-metre width (i.e. 100 columns) excluding the ends where there is no overlap.

\section{Facilities and measurements}

The Patternator consisted of 200 collections Teflon's tubes in two rows and the tube has $25 \mathrm{~mm}$ inside diameter and $70 \mathrm{~cm}$ height as shown in Figs. 2 and 3. The nozzles were mounted on a X-axis traverse and held in place by a using a clamp assembly. The height of nozzle boom was controlled automatically by the control unit in the full automatic Patternator. Liquid flow to the nozzle was delivered using a pressurized vessel; the GPI Electronic Digital Turbine Meter combine monitored the flow rate. Pressure was monitored immediately upstream of the nozzle body. Manometer pressure was monitored using a 0-1500 kPa, class 3A pressure gauge. All instruments were connected and programmed under AW system. Temperature and humidity were measured using a CMP (Constant Multi Pulse) measurements probe system with data logger. The Tee Jet TT110-3 POM, Tee Jet TT110-5 POM, Lechler LU120-15 POM, Lechler LU120-04 POM, Lechler LU90-04 POM, Lechler AD120-04 POM, Tee Jet XR8003 VS, and Tee Jet DG8004 VK were selected to make the EMTF nozzles and operated at low liquid pressure.

\section{External Mixing Twin Fluid nozzles (EMTF)}

The EMTF nozzle was developed in Hohenheim University, Germany as the part of the applicable technique for the biological material (Sehsah, 2005, Sehsah, \& Ganzelmeier, 2010, and Sehsah \& Herbst, 2010). The principle of the external mixing twin fluid nozzle is the injection of a liquid sheet into air sheet, both produced by tongue nozzles. At the merging line, the high-speed air stream will disintegrate the liquid sheet and produce droplets. With External mixing twin fluid nozzles, the liquid sheet or jet exposed to the atomizing air has little initial momentum and the droplets formed in atomization are entirely dependent on the kinetic energy of the atomizing air to transport them away from the nozzle into the target. The combination of the EMTF nozzle were selected and illustrated in table 1 and Fig. 4. 


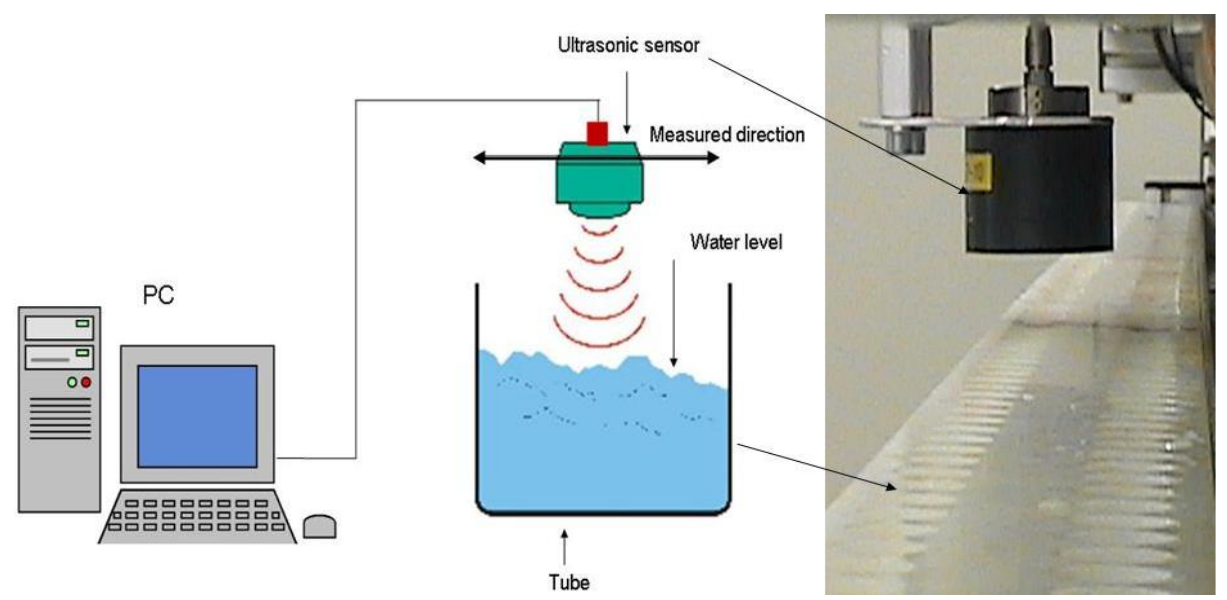

Fig. 1: The schismatic diagram of ultrasonic setup in full automatic Patternator in JKI laboratory.

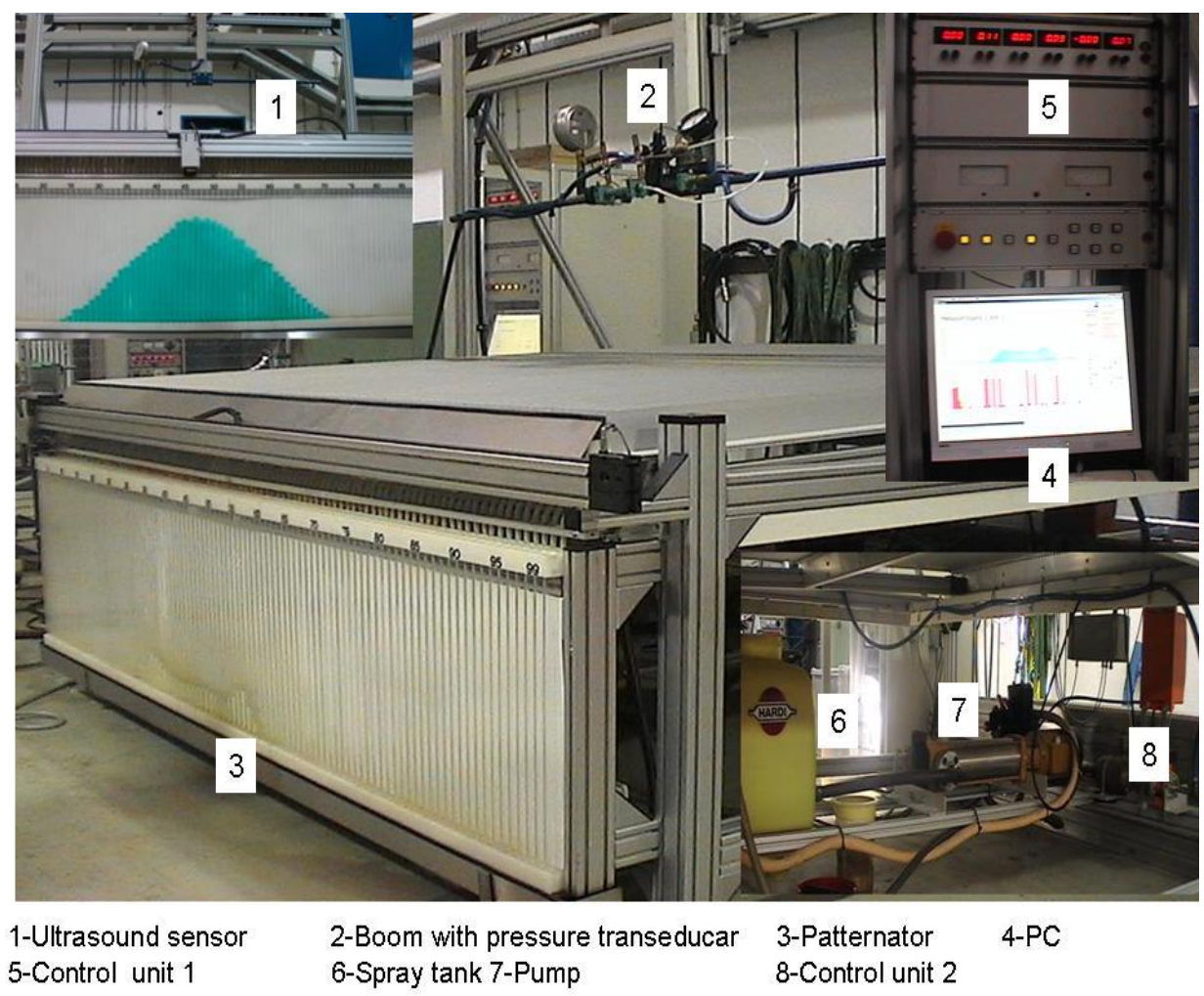

Fig. 2: The full automatic Patternator for tests spray distribution of single nozzle in JKI laboratory. 
The full automatic Patternator used in the Laboratory of JKI to test the new nozzles which produced in the marketing for agricultural field. The JKI make the recommendation and reported to evaluate the new nozzles for EU countries.

Table 1: The combinations of external mixing twin fluid (EMTF) nozzles

\begin{tabular}{ccc}
\hline EMTF & \multicolumn{2}{c}{ Nozzles } \\
\cline { 2 - 3 } Nozzles & Air nozzles & Liquid nozzles \\
\hline N 1 & Lechler FT 5 - 608 & Tee Jet TT110-3 POM \\
N 2 & Lechler FT 5 - 608 & Tee Jet TT110-5 POM \\
N 3 & Lechler FT 5 - 608 & Lechler LU120-15 POM \\
N 4 & Lechler FT 5 - 608 & Lechler LU120-04 POM \\
N 5 & Lechler FT 5 - 608 & Lechler LU90-04 POM \\
N 6 & Lechler FT 5 - 608 & Lechler AD120-04 POM \\
N 7 & Lechler FT 5 - 608 & Tee Jet XR8003 VS \\
N 8 & Lechler FT 5 -608 & Tee Jet DG8004 VK \\
\hline
\end{tabular}

\section{Procedures}

The current research investigates the distribution for the developed low pressure external mixing twin fluid (EMTF) nozzle under laboratory conditions. The mean treatments for the current study are the type of nozzles in the EMTF combinations nozzles, nozzles height, co-angling (injection angle) and air pressure for EMTW nozzles that affecting on the spray uniformity distribution. The duration of spraying experiments are controlled by the AW system, each treatment operated for 240 second. Spray pressures of $150 \mathrm{kPa}$ and $60 \mathrm{kPa}$ are applied for reference nozzles and the EMTF nozzles respectively. The control valves in the full automatic Patternator were adjusted the pressure nozzles. The single nozzle in boom fixed at middle of the top on the patternator. The single nozzle was used to reduce the overlap that produced at using for several nozzles. To enable the height of nozzle of spray boom to be treated, the nozzle was mounted on the transporter.

The control unit for liquid pressure and flow-rate adjusted before the single EMTF nozzle used to obtain the operating pressure nozzles for every treatment. By operating of the sprayer and the compressor of air, the patterns for every nozzle were measured by the ultrasonic sensor as above mentioned and record to analyze the data. 

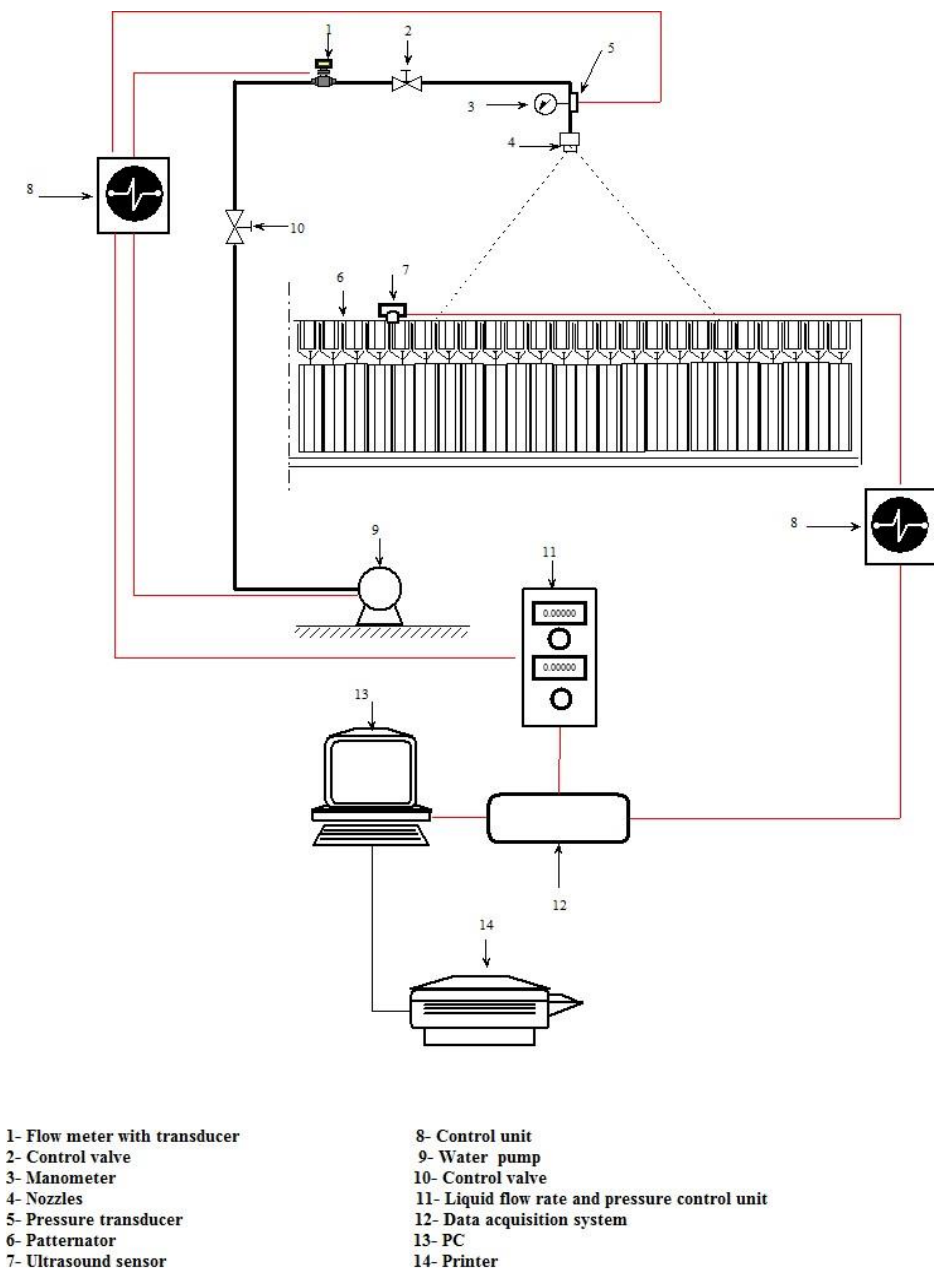

8- Control unit

9- Water pump

10- Control valve

11- Liquid flow rate and pressure control unit

12-Data acquisition system

13- PC

7- Ultrasound senso

14- Printer

Fig. 3: The Schematic diagram of the Patternator system and their facilities to the spray distribution of single nozzle.

As well as, measurements were carried out through the long axis of the spray distribution at a constant scan speed. All measurements were made spraying water at a temperature of approximately $20^{\circ} \mathrm{C}$. Environmental conditions were kept constant at a temperature of $20^{\circ} \mathrm{C}$ and a relative humidity between 70 and $80 \%$. Three replications are used for every treatment to obtain a high accuracy analysis of the results. The arrangement and statistical analysis of the experiments was according to randomized block design. 


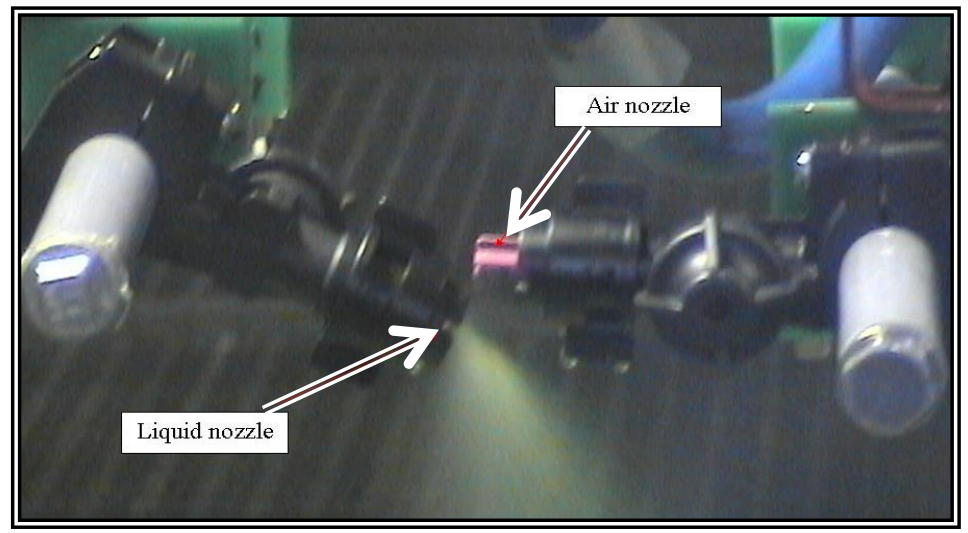

Fig. 4: The combination of a tongue nozzle (Lechler FT5.0- 608) for the air and a Tee Jet XR8004 VK for the liquid spray.

The hypotheses of the data analysis were to assume that the spray pattern distribution is affected by a number of factors and situations. The factors are the combination of EMTF nozzles, height of nozzle and injection angle. These include the pressure of air which used to atomize the liquid spray by Lechler FT 5 - 608 air nozzle. The conventional standard flatfan Hardi ISO F 110-03 nozzles are used as the reference nozzles and compared its CV \% result with the eight selected EMTF nozzles. The first and last tests of each of the measuring treatment were carried out using the Hardi ISO F 110-03 reference nozzle at $300 \mathrm{kPa}$ to provide direct comparison with the spray distribution data at two different nozzle height $50 \mathrm{~cm}$ and $70 \mathrm{~cm}$. The eight selected EMTF nozzles (Tee Jet TT110-3 POM, Tee Jet TT110-5 POM, Lechler LU120-15 POM, Lechler LU120-04 POM, Lechler LU90-04 POM, Lechler AD120-04 POM, Tee Jet XR8003 VS, and Tee Jet DG8004 VK) were operated at $60 \mathrm{kPa}$ low 
liquid pressure. The two levels of air pressures in eight selected EMTF nozzles 150 (1.5 bar) and $200 \mathrm{kPa}$ (2 bar) at liquid pressures $60 \mathrm{kPa}(0.6$ bar), two height of nozzle $50 \mathrm{~cm}$ and $70 \mathrm{~cm}$, and two injection angles $60^{\circ}$ and $45^{\circ}$ were tried to study their effect on spray distribution, as well as to find the optimal nozzle configuration.

\section{Coefficients of Variation (CV, \%)}

The AW system software program was used and with VB programming programmed the coefficient of variation. The coefficients of variation as the percentage of spray pattern for all nozzles treatment were programmed by using the standard equation and excluding the ends where there is no overlap. The coefficient of variation was programmed using the following formula (Herbst, A. and P. Wolf, 2001): Where C.V. is the coefficients of variation percentage, $\%, \mathrm{x}_{\mathrm{i}}$ is the height of liquid in the tube, $\mathrm{cm}$ and, $\mathrm{n}$ is the number of patternator columns.

In figure 5, indicates the test report for the EMTF nozzles which reported by the JKI in Braunschweig, Germany. This recommendation report is required to accept any new nozzles in EU countries. The data for every treatment were collected from the all reports for every treatment conditions. The spray volume in every tubes which measured by the Ultrasonic sensor were used to recalculated the $\mathrm{CV} \%$ values. The $\mathrm{CV} \%$ values were recalculated by using the functions 1,2 , and 3 as above mentioned to obtain a good accuracy for the CV \% because the AW system programming sometimes give only an error values for $\mathrm{CV} \%$.

$X^{\prime}=\frac{\sum X_{i}}{n} \ldots \ldots \ldots \ldots \ldots . .(1), s=\sqrt{\frac{\sum\left(x_{i}-x^{\prime}\right)^{2}}{n-1}} \ldots \ldots \ldots(2)$ and $C V=\frac{s}{x^{\prime}} * 100$

\section{RESULTS AND DISCUSSIONS}

In the current investigation research, it will be investigate the spray distribution for different EMTF nozzles at different treatment tests conditions. The different combinations of EMTF nozzles, height of nozzle, air pressure, and co-angling are the main factor of treatment which affecting on the spray uniformity. 


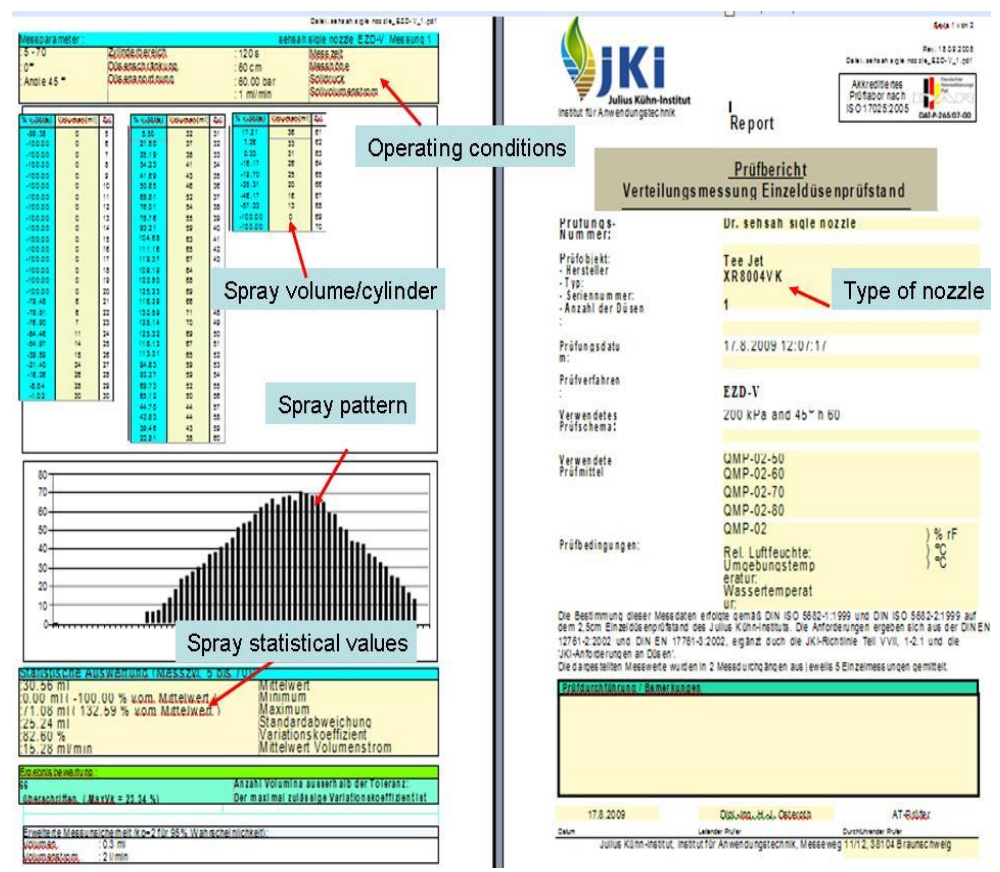

Fig. 5: The output results and the JKI recommendation reporter from AW system software program for the evaluation of the EMTF nozzles.

\section{The uniformity distribution}

The Coefficients of variation for all treatments are given in Tables 2, 3, 4 and 6 from the statistical analysis of these parameter data. It was shown that, the spray distribution is improved by good select of type of nozzles in the combination of EMTF nozzles, increasing of air pressure, reduces co-angling of nozzles and reduces the nozzle height. The type of nozzles is very important parameters which affect the distribution of pattern $\mathrm{CV}$, $\%$ values as shown in Tables 2, 3, 4, and 6. The low value of coefficient (CV) of variation represents an indicator for good uniformity distribution. The combination of EMTF N3, N7 and N8 nozzles gave the better uniformity distribution compared to the N1, N2, N4, N5 and N6 EMTF nozzles. The N8 (Lechler FT 5-608 \& DG800-04 VK) nozzle combination gave $11.0 \%$ coefficient of variation percentage at $60 \mathrm{kPa}$ liquid pressure and $50 \mathrm{~cm}$ nozzle height or boom height. On the other hand, the coefficient of variation percentage $(\mathrm{CV}, \%)$ values for standard ISO nozzle at $300 \mathrm{kPa}$ nozzle pressure were $10.2 \%$ and $12.6 \%$ at $50 \mathrm{~cm}$ 
and $70 \mathrm{~cm}$ nozzle height respectively. The selection of nozzles may be reduced the losses of spray dose and gives good distribution of pattern.

\section{Effect of nozzle types and nozzle height on CV \%}

It is clearly that the types of nozzle in the external mixing twin fluid (EMTF) combined nozzles has an important influence on the reduction of the coefficient of variation percentage compared to the ISO 03 nozzle as shown in figure 6, 7 and 8 . In table 2, the effect of the interaction of different EMTF nozzles type, nozzle height and co-angling were investigated to find their affecting on spray uniformity $\mathrm{CV}$ percentages. The interaction between nozzles type, nozzle height and co-angling was significant at $5 \%$ level. The EMTF nozzle types N3, N7, and N8 produced the lowest $\mathrm{CV} \%$ values compared to the N1, N2, N4, N5 and N6. On the other hand, the EMTF nozzle N8 (Lechler FT 5-608 \& DG800-04 VK) produced the CV \% nearly the standard ISO nozzle CV percentages values. Table 3 indicates the effect of the interaction of different EMTF nozzles type, height of nozzle and air pressure for EMTF nozzles were investigated to find their affecting on spray uniformity /CV percentages. The interaction between nozzles type, nozzle height and air pressure was non-significant at $5 \%$ level. This result means that, it may able to use the low air pressure $150 \mathrm{kPa}$ to operate the EMTF nozzles and reducing the energy and power requirement for EMTF nozzles. Table 4 illustrates the effect of the interaction of different EMTF nozzles type, coangling and air pressure for EMTF nozzles were investigated to find their affecting on spray uniformity $\mathrm{CV}$ percentages. The interaction between nozzles type, co-angling $45^{\circ}$ and air pressure was significant but the coangling $60^{\circ}$ was non-significant effect at $5 \%$ level. Table 5 displays the interaction for all factors nozzles type, nozzle height, co-angling and air pressure for EMTF nozzles were investigated to find their affecting on spray uniformity CV percent. It noticed that, there are significant effects for nozzles type, nozzle height, co-angling and air pressure on spray uniformity $\mathrm{CV}$ percentages at $5 \%$ level. The minimum $\mathrm{CV} \%$ values for good spray distribution at $50 \mathrm{~cm}$ nozzle height, $45^{\circ}$ co-angling and 200 $\mathrm{kPa}$ air pressure were $10.6 \%, 12.9 \%$ and $14.0 \%$ for EMTF nozzle N8, $\mathrm{N} 3$ and N7, respectively. 
The EMTF nozzle N8 produced the CV \% nearly the standard ISO nozzle $\mathrm{CV}$ percentages values. In figures 6 , indicate that there are non-significant different between the N8 (Lechler FT 5-608 \& DG800-04 VK) EMTF nozzle and standard ISO nozzle at both nozzle height $50 \mathrm{~cm}$ and $70 \mathrm{~cm}$. As well as the differences were statistically non-significant for the affecting of type of nozzles in EMTF nozzles combinations at two levels of co-angling on the spray distribution as shown in figure 7. It is clear that the external mixing twin fluid nozzles may be producing a good spray distribution at low liquid pressure. It is observed that the combinations of the external mixing twin fluid nozzles gave the highly effect on the CV \% compared to the other factors, height nozzle, injection angle and air pressures. The external mixing twin fluid nozzle N1 (TT11003+ Lechler FT 5 - 608) produced the highest CV \% compared to the N8 (Lechler FT 5-608 \& DG800-04 VK) nozzles combinations at low liquid pressure 60 $\mathrm{kPa}(0.6$ bar). It may therefore be concluded that the $\mathrm{CV} \%$ values are more strongly dependant on the combinations of nozzles in the EMTF nozzles, which is highly significant in data.

In table 5, the effect of nozzles height was significant effect on CV \% values of spray uniformity at both two levels of co-angles and air pressure. As well as, increasing of nozzle height tends to increase the CV percentages. The nozzle height $50 \mathrm{~cm}$ produced a good distribution compared to $70 \mathrm{~cm}$ height of nozzle as shown in table 5 and figure 6 . AS well as, the combination of chosen testing height and co-angling therefore will affect $\mathrm{CV}$ s from each particular nozzle.

\section{Effect of the co-angling on $\mathrm{CV} \%$}

In table 2, the co-angling (injection angle) was significant effect on the CV \% for all EMTF nozzles combinations N1, N3, N4, N5, N6, N7 and $\mathrm{N} 8$. On the other hand, the increase of injection angle tends to increase the $\mathrm{CV} \%$ or losses of spray liquid. The injection angle $60^{\circ}$ at $150 \mathrm{kPa}(1.5$ bar) air pressure gave the highest value of the CV \% as shown in table 2 and figure 7. As well as, it was found that the $45^{\circ}$ at $50 \mathrm{~cm}$ nozzle height gave a significant effect compared to the $60^{\circ}$ injection angle at same condition. The $45^{\circ}$ co-angling produced a good spray uniformity distribution compared to the $60^{\circ}$ co-angling. A similar trend was found for the effect of the $45^{\circ}$ at $200 \mathrm{kPa}$ air pressures on the $\mathrm{CV} \%$. In figure 7 
presented that the interaction of the effect of the type of nozzles and injection angle on the CV\%. The optimum co-angling for EMTF nozzles was found at $45^{\circ}$ that may be reduce the spray losses and produced a good uniformity spray distribution for all treatment conditions. The uniformity spray distribution CV percent values for N8 (Lechler FT 5-608 \& DG800-04 VK) nozzle at the optimum co-angling $45^{\circ}$ were $11.0 \%$ and $12.1 \%$ at $50 \mathrm{~cm}$ and $70 \mathrm{~cm}$ nozzle height respectively. As well as the CV percent values for above nozzle at $60^{\circ}$ co-angling were $13.2 \%$ and 14.1 $\%$ at $50 \mathrm{~cm}$ and $70 \mathrm{~cm}$ nozzle height respectively. In addition to, the both $45^{\circ}$ and $60^{\circ}$ co-angling were non-significant effect on the CV percent values for interaction of the nozzles height, co-angle and air pressure. The $\mathrm{CV}$ percent values for $150 \mathrm{kPa}$ air pressure were $17.7 \%$ and $18.5 \%$ at nozzle height $50 \mathrm{~cm}$ for $45^{\circ}$ and $60^{\circ}$ co-angling as shown in table 5 , respectively. As well as, there are non effects of the interaction of coangling with the all factors on the CV percentage as shown in table 6 . The CV percent values for N8 (Lechler FT 5-608 \& DG800-04 VK) nozzles combinations and $150 \mathrm{kPa}$ air pressure were $13.2 \%$ and $14.5 \%$ at nozzle height $50 \mathrm{~cm}$ for $45^{\circ}$ and $60^{\circ}$ co-angling as shown in table 6 respectively. It may be able to use the $45^{\circ}$ co-angling that will be easy to setting it by the operator.

\section{Effect of air pressure on CV \%}

In tables 4, 5 and 6, the air pressure was non-significant effect on the CV $\%$ for all combined of EMTF nozzles N1, N2, N3, N4, N5, N6, N7 and N8. It is clearly that the air pressure is non importance factor affecting on the spray uniformity distribution pattern $\mathrm{CV}$ percentage. On the other hand, the statistical analysis indicated that, the interaction between the air pressures with injection angle was also non-significant effect on spray pattern distribution as shown in tables 5 and 6 . A similar tendency was found in the effect of the interaction of air pressures with nozzle height on the CV percentage as shown in table 5. As well as, there are non effects of the interaction of air pressures with the all factors on the CV percentage as shown in table 6. The CV percent values for N8 (Lechler FT 5-608 \& DG800-04 VK) nozzle and nozzle height $50 \mathrm{~cm}$ were $11.3 \%$ and $10.6 \%$ at air pressure $150 \mathrm{kPa}$ and $200 \mathrm{kPa}$ and co-angling $45^{\circ}$ respectively. As well as, the CV percent values for N8 (Lechler FT 5-608 \& DG800-04 
VK) nozzle and nozzle height $50 \mathrm{~cm}$ were $11.8 \%$ and $12.3 \%$ at air pressure $150 \mathrm{kPa}$ and $200 \mathrm{kPa}$ and co-angling $60^{\circ}$ respectively.

Table 2: The effect of combinations of the external mixing twin fluid (EMTF) nozzles, nozzles height and co-angle on $\mathrm{CV} \%$ values of spray uniformity

\begin{tabular}{c|c|c|c|c}
\hline \multirow{2}{*}{ EMTF nozzles } & \multicolumn{4}{|c}{ Spray uniformity, CV \% } \\
\cline { 2 - 5 } & \multicolumn{2}{|c}{ Nozzle height, 50 cm } & Nozzle height, 70 cm \\
\cline { 2 - 5 } & $\begin{array}{c}\text { Co-angle, } \\
45^{\circ}\end{array}$ & $\begin{array}{c}\text { Co-angle, } \\
60^{\circ}\end{array}$ & $\begin{array}{c}\text { Co-angle, } \\
45^{\circ}\end{array}$ & $\begin{array}{c}\text { Co-angle, } \\
60^{\circ}\end{array}$ \\
\hline \multirow{2}{*}{ N1 } & 22.3 & 26.8 & 24.5 & 28.7 \\
N2 & 19.7 & 24.1 & 21.4 & 23.2 \\
N3 & $\mathbf{1 3 . 3}$ & $\mathbf{1 6 . 1}$ & $\mathbf{1 4 . 7}$ & $\mathbf{1 7 . 2}$ \\
N4 & 17.8 & 21.4 & 19.6 & 22.9 \\
N5 & 18.7 & 22.5 & 20.5 & 24.1 \\
N6 & 20.3 & 24.4 & 22.2 & 26.1 \\
N7 & $\mathbf{1 4 . 4}$ & $\mathbf{1 7 . 4}$ & $\mathbf{1 5 . 9}$ & $\mathbf{1 8 . 6}$ \\
N8 & $\mathbf{1 1 . 0}$ & $\mathbf{1 3 . 2}$ & $\mathbf{1 2 . 1}$ & $\mathbf{1 4 . 1}$ \\
\hline SE & 0.37380 & $5 \%$ LSD & 1.05598
\end{tabular}

Table 3:The effect of combinations of the external mixing twin fluid (EMTF) nozzles, nozzles height and air pressure on $\mathrm{CV} \%$ values of spray uniformity

\begin{tabular}{|c|c|c|c|c|}
\hline \multirow{3}{*}{ EMTF nozzles } & \multicolumn{4}{|c|}{ Spray uniformity , CV \% } \\
\hline & \multicolumn{2}{|c|}{ Nozzle height, $50 \mathrm{~cm}$} & \multicolumn{2}{|c|}{ Nozzle height, $70 \mathrm{~cm}$} \\
\hline & $150 \mathrm{kPa}$ & $200 \mathrm{kPa}$ & $150 \mathrm{kPa}$ & $200 \mathrm{kPa}$ \\
\hline N1 & 23.5 & 23.3 & 28.1 & 27.4 \\
\hline $\mathrm{N} 2$ & 20.8 & 20.3 & 23.6 & 23.8 \\
\hline $\mathbf{N 3}$ & 14.1 & 13.9 & 16.8 & 16.4 \\
\hline N4 & 18.8 & 18.6 & 22.4 & 21.9 \\
\hline N5 & 19.7 & 19.5 & 23.6 & 23.0 \\
\hline N6 & 21.3 & 21.2 & 25.5 & 24.9 \\
\hline N7 & 15.2 & 15.1 & 18.2 & 17.8 \\
\hline N8 & 11.6 & 11.5 & 13.8 & 13.5 \\
\hline L & .373801 & $5 \% \mathrm{LS}$ & & \\
\hline
\end{tabular}


Table 4:The effect of combinations of the external mixing twin fluid (EMTF) nozzles, co-angle and air pressure on $\mathrm{CV} \%$ values of spray uniformity

\begin{tabular}{|c|c|c|c|c|}
\hline \multirow{3}{*}{ EMTF nozzles } & \multicolumn{4}{|c|}{ Spray uniformity, CV \% } \\
\hline & \multicolumn{2}{|c|}{$45^{\circ}$ Co-angle } & \multicolumn{2}{|c|}{$60^{\circ}$ Co-angle } \\
\hline & $150 \mathrm{kPa}$ & $200 \mathrm{kPa}$ & $150 \mathrm{kPa}$ & $200 \mathrm{kPa}$ \\
\hline N1 & 24.9 & 24.2 & 26.6 & 26.5 \\
\hline $\mathrm{N} 2$ & 22.1 & 21.8 & 22.3 & 22.4 \\
\hline $\mathbf{N 3}$ & 14.9 & 14.5 & 16.0 & 15.9 \\
\hline N4 & 19.9 & 19.3 & 21.3 & 21.2 \\
\hline N5 & 20.9 & 20.3 & 22.4 & 22.2 \\
\hline N6 & 22.6 & 22.0 & 24.2 & 24.1 \\
\hline N7 & 16.2 & 15.7 & 17.3 & 17.2 \\
\hline N8 & 12.3 & 11.9 & 13.1 & 13.1 \\
\hline SE & .37380 & $5 \% \mathrm{LSL}$ & 1.0 & \\
\hline
\end{tabular}

Table 5:The effect of nozzles height, co-angle and air pressure effect on $\mathrm{CV} \%$ values of spray uniformity

\begin{tabular}{c|c|c|c|c}
\hline \multirow{2}{*}{$\begin{array}{c}\text { EMTF nozzles height, } \\
\mathrm{cm}\end{array}$} & \multicolumn{3}{|c}{ Spray uniformity , CV \% } \\
\cline { 2 - 5 } & \multicolumn{2}{|c|}{ Co-angle $45^{\circ}$} & \multicolumn{2}{c}{ Co-angle $60^{\circ}$} \\
\cline { 2 - 5 } & $150 \mathrm{kPa}$ & $200 \mathrm{kPa}$ & $150 \mathrm{kPa}$ & $200 \mathrm{kPa}$ \\
\hline 50 & 17.7 & 16.6 & 18.5 & 19.2 \\
70 & 20.7 & 20.8 & 22.3 & 21.4 \\
\hline
\end{tabular}

$\begin{array}{llll}\text { SE } & 0.186901 & 5 \% \text { LSD } & 0.527988\end{array}$

It was no different between the CV percent values for same EMTF nozzle N8 (Lechler FT 5-608 \& DG800-04 VK) at nozzle height $70 \mathrm{~cm}$ and coangling $45^{\circ}$ for both air pressure $150 \mathrm{kPa}$ and $200 \mathrm{kPa}$. The air pressure $150 \mathrm{kPa}$ produced the nearly $\mathrm{CV} \%$ values compared to $200 \mathrm{kPa}$ air pressure for all EMTF nozzles. In figure 8 illustrate no different $\mathrm{CV} \%$ values between the two air pressure $150 \mathrm{kPa}$ and $200 \mathrm{kPa}$. It may be able to use the low air pressure to reduce the power requirements in the operation of EMTF nozzles. 
Table 6:The effect of combinations of the external mixing twin fluid (EMTF) nozzles, nozzles height, co-angle and air pressure on $\mathrm{CV} \%$ values of spray uniformity

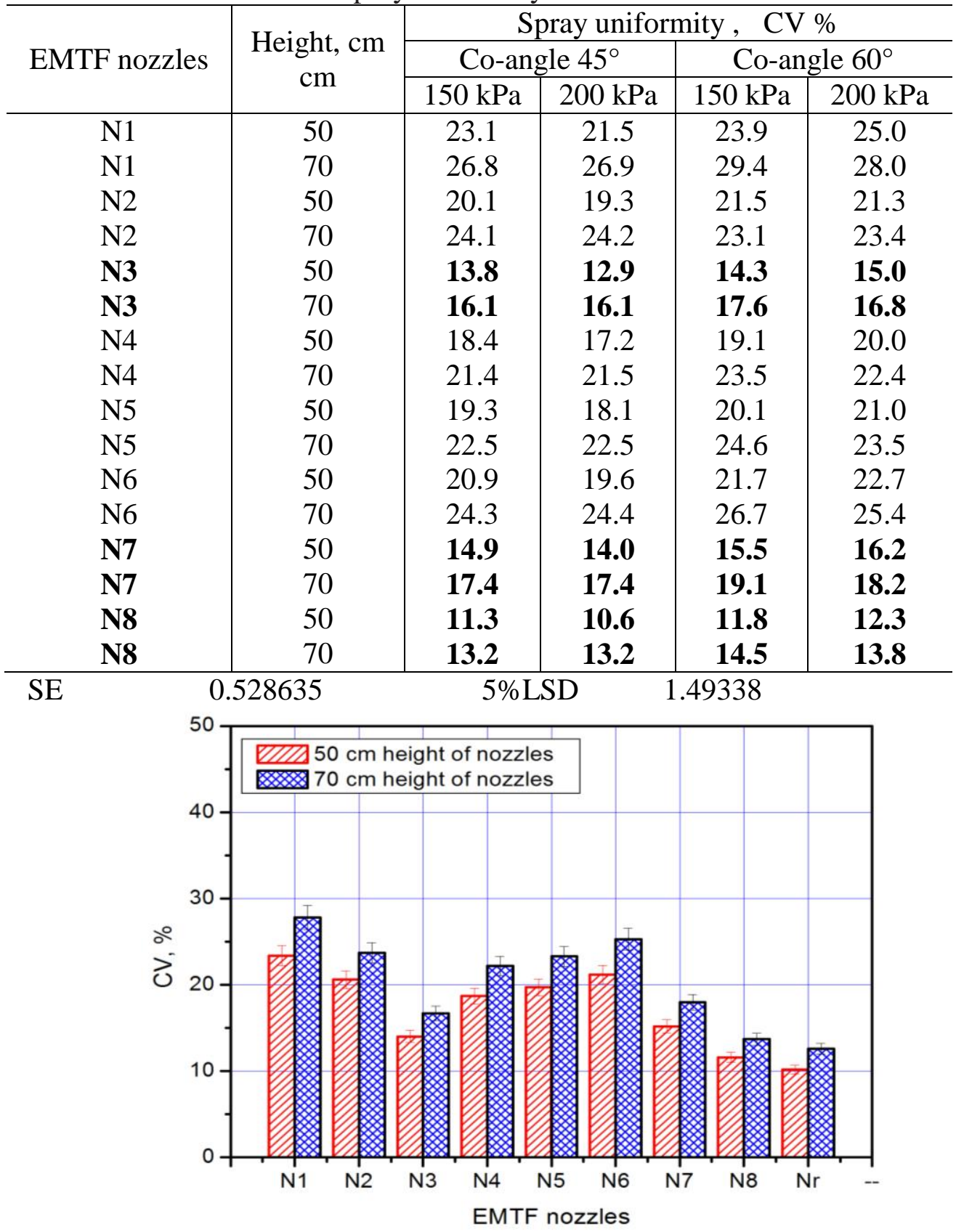

Fig. 6: The effect of type of EMTF nozzles, nozzles height on the spray distribution, $\mathrm{CV} \%$. 


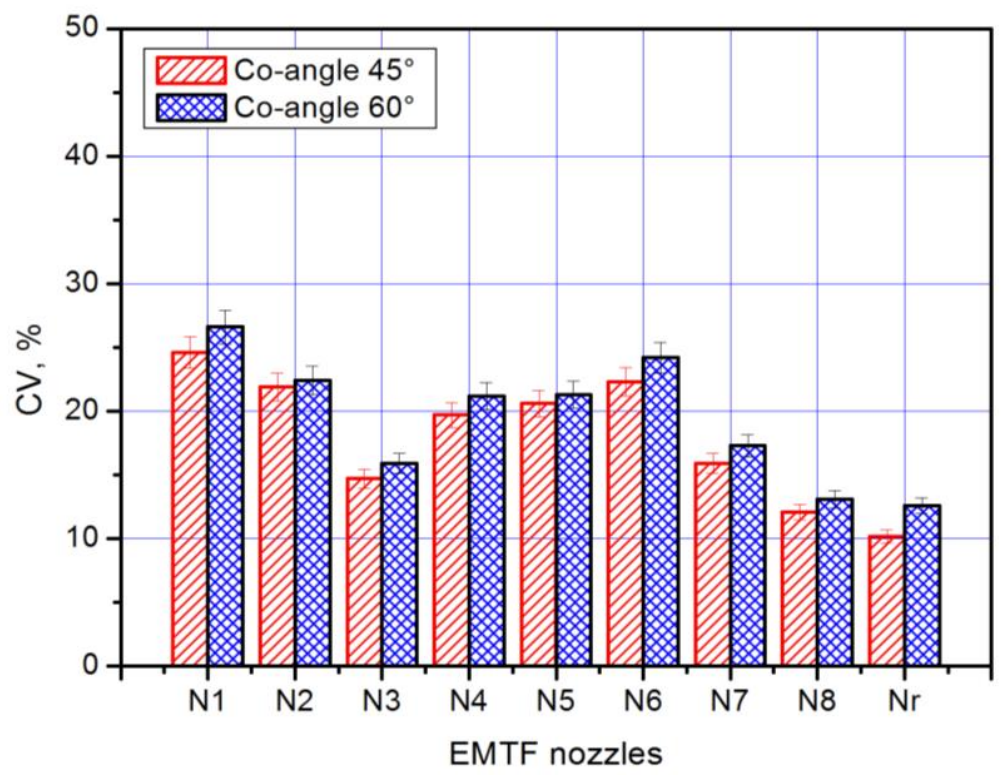

Fig. 7: The effect of type of EMTF nozzles and co-angling of EMTF nozzles on the spray distribution, $\mathrm{CV} \%$.

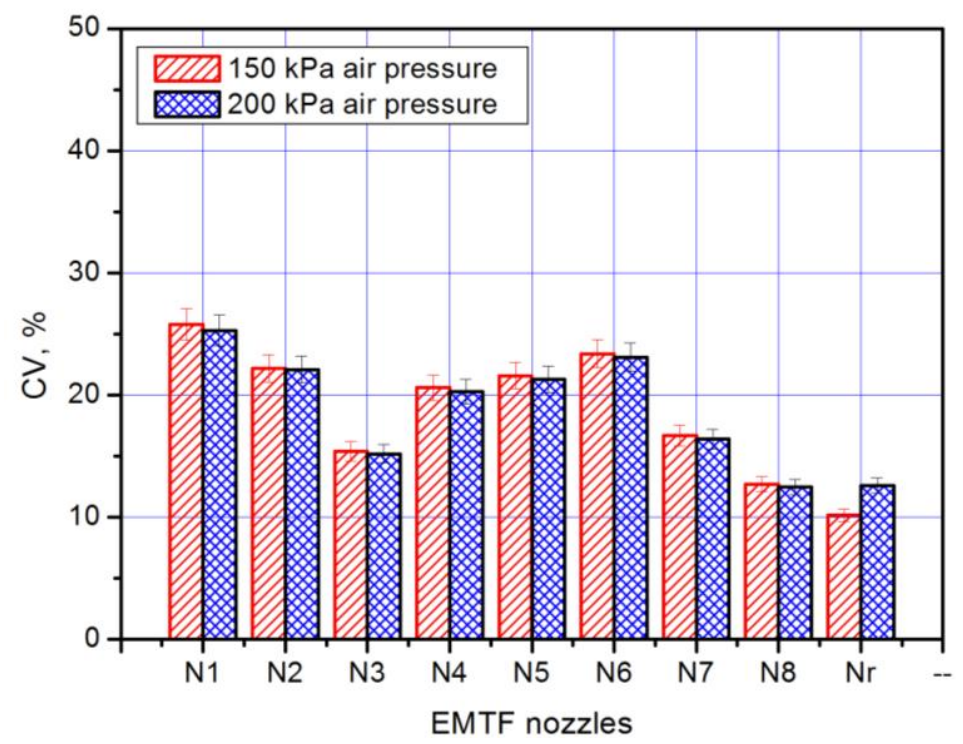

Fig. 8: The effect of type of EMTF nozzles and air pressure of EMTF nozzles on the spray distribution, CV\%. 


\section{CONCLUSIONS}

From the above two research parts that focused on the investigations and evaluation of new EMTF nozzles. The EMTF nozzles may able to produce the spray spectra from fine to very fine droplets with low power requirement. In addition, the EMTF nozzles may be able to reduce the drift, soil sedimentation and good deposition values. The results indicated that the nozzle types and nozzles height affect the spray uniformity distribution. The decreasing of nozzle height tends to increase the uniformity of spray and the coverage of spray dose. As well as, there is non-significant effect of air pressure under laboratory condition on uniformity of dose. For the different EMTF nozzle combinations, CV \% values of the N8 nozzle which combined from Lechler FT 5-608 with Tee Jet DG8004 VK nozzle was always nearly than the CV \% values compared to the standard ISO nozzle at liquid pressure $60 \mathrm{kPa}(1 \mathrm{bar})$ and $50 \mathrm{~cm}$ nozzle height. The optimum co-angling for EMTF nozzles was found at $45^{\circ}$ that may be reduce the spray losses and produced a good uniformity spray distribution As well as, it may able to use the low air pressure $150 \mathrm{kPa}$ to operate the EMTF nozzles and reducing the energy and power requirements.

\section{Acknowledgements}

The author would like to acknowledge the JKI, Applied Technique Division in Braunschweig, Germany and Research Unit staff for their support and use of the full automatic Patternometer to complete this study. Special thanks are offered to Prof. Dr. H. Ganzelmeier in JKI and Dr. R. Heinkel from Lechler Company.

\section{REFERENCES}

Alford, J; Miller, P C H; Goulson, D; Holland, J M (1998): ' Predicting susceptibility of non- target insect species to different insecticide application in winter wheat.' Proc Brighton Conf - Pests and Diseases. pp $599-604$.

Chapple, A C; Downer, R A; Hall F R (1993): 'Effects of spray adjuvants on swath patterns and droplet spectra for a flat fan hydraulic nozzle.' Crop Protection, 12. pp 579 -590.

Combellack, J H; Miller, P C H (2001): 'Effect of adjuvants on spray patternation and the volume of air inducted by selected nozzles.' 
Proc Sixth Int Symposium on Adjuvants for Agrochemicals. pp 557 -562 .

Czacyk, Z; Kramer, H; Kleisinger, S (2002): 'Comparison of two abrasive materials for testing nozzle wear.' Aspects of Applied Biology, 66. pp 457 - 461.

Dorr, G J and Pannell, D J (1992): 'Economics of improved spatial distribution of herbicide for weed control in crops.' Crop Protection, 11. pp 385 - 390.

Downer, R A; Ebert, T A; Thompson, R S; Hall, F R (1997): 'Herbicide spray distribution, quality and efficacy interactions; conflicts in requirements .'Aspects of Applied Biology, 48. pp 79 - 89.

Enfalt, P; Engqvist, A; Alness, K (1997a): 'Assessment of the dynamic spray distribution on a flat surface using image analysis.' Aspects of Applied Biology, 48. pp 17 - 24.

Enfalt, P; Engqvist, A; Bentsson, P (1997b): 'The influence of spray distribution and drop size on the dose response of herbicides.'Proc Brighton Crop Protection Conf - Weeds. pp 381 -389 .

Ford, M G and Salt, D W (1987): 'The behavior of insecticide deposits and their transfer from plant to insect surfaces.' In 'Pesticides on plant surfaces. Critical reports in applied chemistry.' Ed H Cottrell. John Wiley.

Hagenvall, H (1981): 'Uneven spraying - effects on yield and weeds.' Proc 22nd Swedish Weed Conf (Reports). pp 96 - 105.

Herbst, A; Wolf, P (2001): 'Spray deposit distribution from agricultural boom sprayers in dynamic conditions.' ASAE Meeting Paper $01-1054$.

Holland, J M; Jepson, P C; Jones, E C; Turner, C (1997): ‘A comparison of spinning disc atomisers and flat fan pressure nozzles in terms of pesticide deposition and biological efficacy within cereal crops.' Crop Protection, 16. pp 179 - 185.

Koch, H (1992): 'Uber die Bedeutung von geratetechnisch determinierten and stochastisch ablaufenden Prozessen des Applikationsvorgangs 
für Dosierung und Veritelung von Pflanzenschuzmitteln.' Gesunde Pflanzen, 44. pp 350 - 360.

Koch, H; Weisser, P (1996): 'Dosierung und Applikationsqualitat bei Verwendung einer Laborspritzbahn in der Prufung von Pflanzenschutzmitteln.'Nachrichtenbl. Deut. Pflanzenschutzd, 48. pp $176-180$.

Knott, L (1978): 'Einfluss horizontaler Spritzgestangeschwankungen auf die Langsverteilung.' Gesunde Pflanzen, 30. pp $42-48$.

Krueger, H R; Reichard, D L (1985): 'Effect of formulations and pressure on spray distribution across the swath with hydraulic nozzles .'Pesticide Formulations and Application Systems: Fourth Symposium. pp 113 - 121. ASTM.

Lloyd, G A; Bell, G J; Howarth, J A; Samuels, S W (1988): 'Rotary atomisers: comparative spray drift study.' MAFF.

Lund, I; Jensen, P K (2002): 'Application technology for band spraying: Correlation between liquid band distribution and biological efficacy.' Aspects of Applied Biology, 66. pp 107 - 114.

Murphy, S D; Miller, P C H; Parkin, C S (2000): 'The effect of boom section and nozzle configuration on the risk of spray drift.' Journal of $\mathrm{Ag}$ Engineering Research, 75. pp 120-137.

Nilars, M S (2002): 'Some nozzle performance considerations when using wide booms at higher spraying speeds.' Aspects of Applied Biology, 66. pp 95 - 106.

Nordbo, E; Taylor, W A (1991): 'The effect of air assistance and spray quality (drop size) on the availability, uniformity and deposition of spray on contrasting targets.' BCPC Mono 46. pp 113 - 124.

Nordbo, E (1992): 'Effects of nozzle size, travel speed and air assistance on deposition on artificial vertical and horizontal targets in laboratory experiments.' Crop Protection, 11. pp $272-278$.

Ozkan, H E; Reichard, D L and Sweeney, J S (1992a): 'Droplet size distribution across the fan patterns of new and worn nozzles.' Trans of the ASAE, 35 (4). pp 1097 - 1102.

Ozkan, H E; Reichard, D L and Ackerman, K D (1992b): 'Effect 
of orifice wear on spray patterns from fan nozzles.' Trans of the ASAE, 35 (4). pp 1091 - 1096.

Richards, M D; Hislop, E C and Western, N M (1997): 'Static and dynamic patternation of hydraulic pressure nozzles.' Aspects of Applied Biology, 48. pp 201 - 208.

Richardson, R G; Combellack J. H and Andrews, L (1985): 'Evaluation of a spray nozzle patternator.' Crop Protection, 5. pp 8-11.

Richardson, B; Schou, W C and Kimberley, M O (2000): 'Defining acceptable levels of spray deposit variation from aerial herbicide applications. 'ASAE Meeting Paper $00-1054$.

Ringel, R; Taylor, W A and Andersen, P G (1991): 'Changing spray deposits from horizontal to vertical surfaces at ground level within cereal rows using air assistance. 'BCPC Mono 46. pp 297 - 298

Sehsah E.M.E. and S. Kleisinger (2009): Study of some parameters effect on spray uniformity distribution pattern. Misr J.Ag.Eng., 26 (1): -

Sehsah E.M.E. and S. Ganzelmeier (2010): Comparison study on Low Pressure EMTF Nozzles based on Droplets Size Characteristics, Misr J.Ag.Eng., 27 (2): -

Sinfort, C and Herbst, A (1996): 'Evaluation of the quality of spray distribution from boom sprayers in practical conditions.' EPPO Bull 26. pp $27-36$.

الملخص العربيى

تقييم كفاعة انتظامية توزيع سائل الرش للفوانى ذات الضغط المنخفض

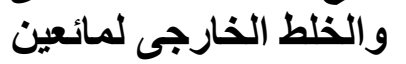

د. السيد محمود البيلى صحصاح

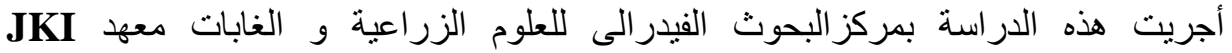
بمدينة برونشفيج بألمانيا. حيث تهدف هذه الزيات (Application Techniques Division)

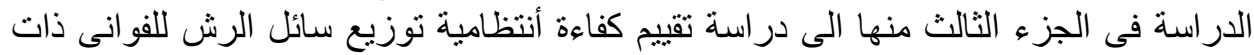

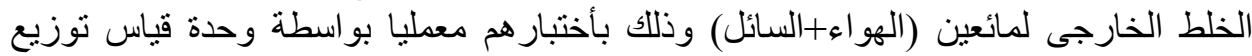

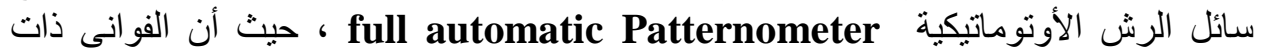
الخلط الخارجى تعتبرمناسبة لتطبيقات المكافحة الحيوية وهى أيضا تقلى التلك من حجم المياه المستعملة فى الرش نظرا لقلة معامل تصرفها و كذلك الطاقة و التكاليف اللازمة لعمليات التيات

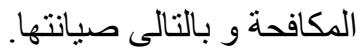

* مدرس بقسم الهندسة الزر اعيةـ كلية الزر اعةـ جامعة كفر الثيخــ مصر. 


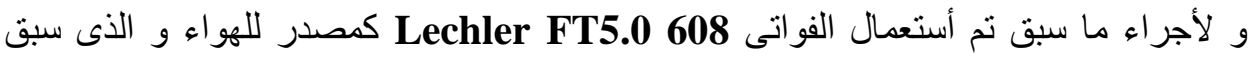

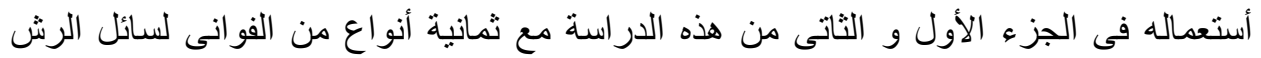
بغرض الحصول على التركيبات التالية N1, N2, N3, N4, N5, N6, N7, N8 من الفو انى التى

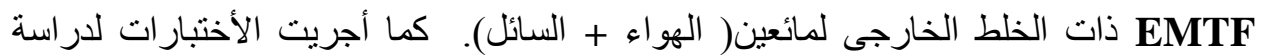

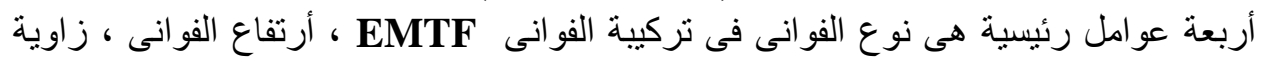

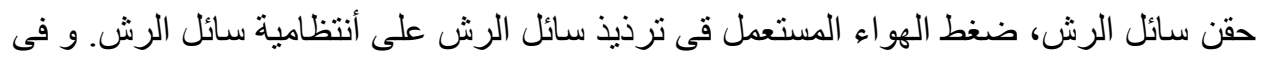

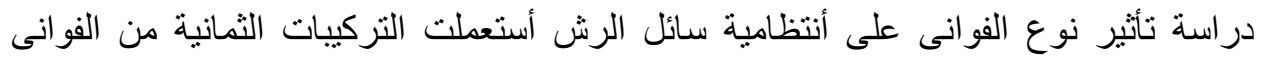
EMTF

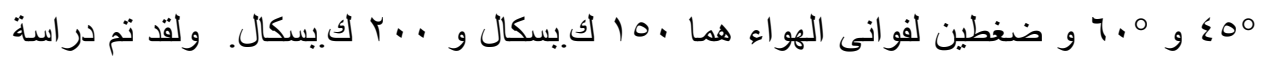

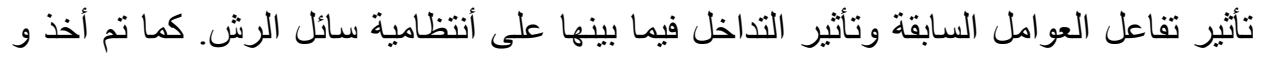

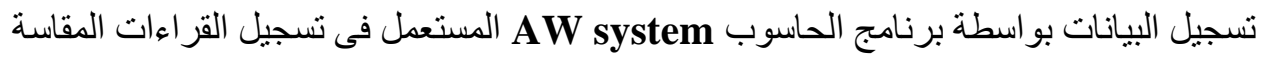

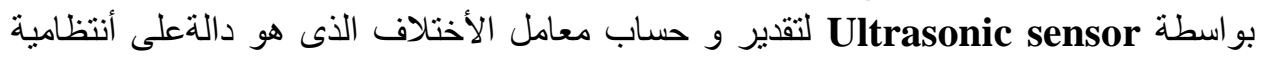

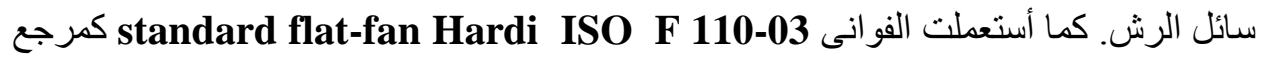

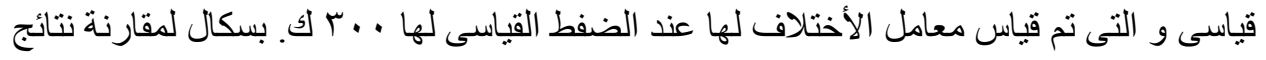

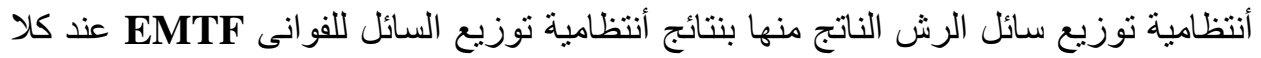

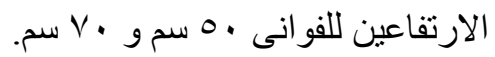

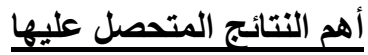

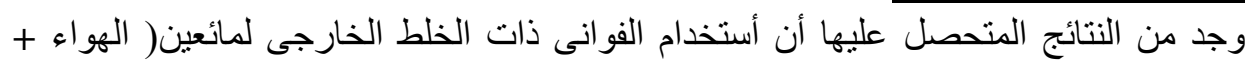
السائل) N8 ذات التركيبة (Lechler FT 5 - 608\&Tee Jet DG80-04 VK)

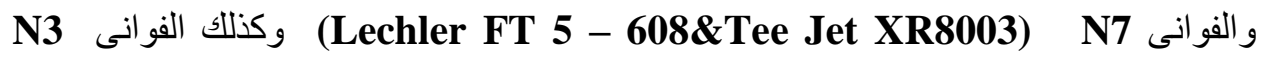
أعطت أقل قيم لمعامل (Lechler FT 5 - 608\&Lechler LU120-15 POM) الأختلاف مقارنة بباقى تركيبات الفوانى N1, N2, , N4, N5, N6 كما أن الفوانى

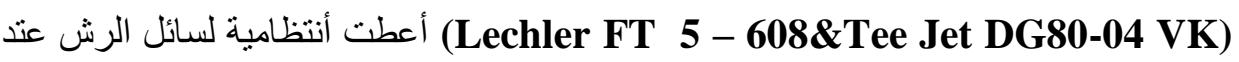

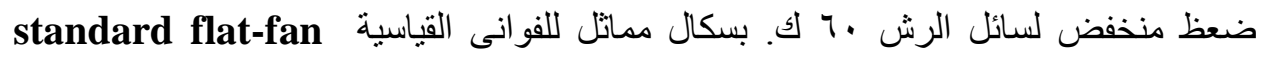

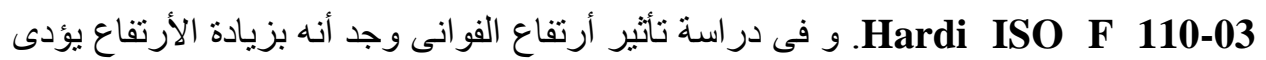

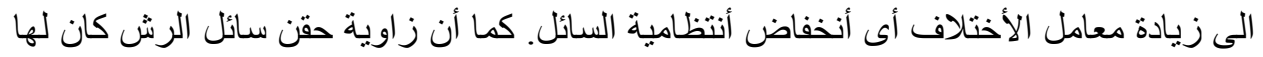

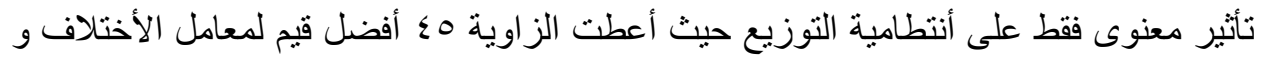

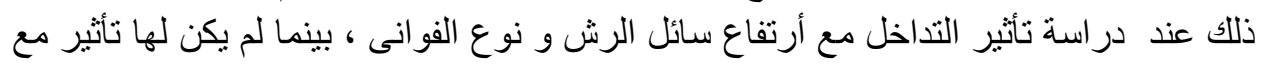

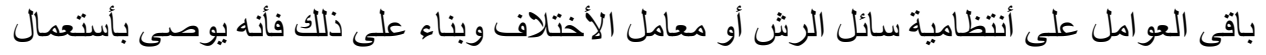

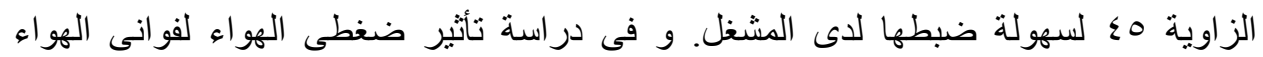
Lechler FT 5 - 608

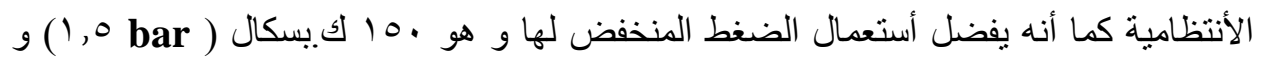
بالتالى خفض القدرة الازمة للتشغيل و التكاليف. 